\title{
Access to Finance for Women-Owned SMEs in Palestine
}

\author{
Dr. Adnan A.A Qubbaja \\ Head of Financial and Banking Science Department, Palestine Ahliya University -Bethlehem
}

\begin{abstract}
The aim of this study is to investigate the effects of collateral requirement, Business support services, High interest on loans, and lack of Information services on access to finance by Women-Owned Small and Medium Enterprises in Palestine, A structured questionnaire was administered on a random sample population of Women-Owned SMEs Enterprises in Hebron and Bethlehem, Out of the 60 questionnaires administered, 54 were filled and returned. This represented a response rate of $90 \%$. Data obtained from the questionnaires were analyzed using the Statistical Package for Social Science(SPSS). Questionnaires were administered on the owners of these SMEs and/ or representatives. Multiple linear regression analysis was used to establish the effects of the market constraints on access to finance by Women-Owned SMEs Enterprises in Palestine. The study indicated that there is a negative correlation between collateral requirements, , High interest on loans, lack of Information services and access to finance by SMEs in Palestine, while there is a positive correlation between Business support services and access to finance SMEs in Palestine. Regression analysis showed that variation in access to finance by SMEs can be explained by collateral requirement, Business support services, High interest on loans, and lack of Information services. The study recommended that, financial institutions should simplify their lending criteria and pay attention to opportunities for financing the promising SME sector rather than requiring high collateral, Government should increase the little support it offers to SMEs, government should launch interest rate-supported programs to enable SMEs access to funds from banks and other financial institutions at low interest rates, increasing the number of intermediaries between the SMEs and the banks to reduce information asymmetry.
\end{abstract}

Keywords: Women-Owned SMEs ,Palestine, Access to Finance.

DOI: $10.7176 /$ RJFA/10-8-12

Publication date: April $30^{\text {th }} 2019$

\section{Introduction}

Small and medium-sized enterprises(SMEs ) have an important contribution in creating inclusive opportunities for women. women-owned SMEs comprise 30 to 37 percent of all SMEs in emerging markets, totaling about 8 to 10 million, women-owned SMEs are fewer in MENA, South Asia and Sub Saharan Africa. Within size class, women own smaller enterprises, and about 20 percent of medium-sized enterprises. Further, a majority of women-owned SMEs are in the retail and wholesale sector (about 40 percent). Data suggest that employment in women-owned SMEs is not necessarily higher than in those owned by men (world Bank, 2016)

According to the (World Bank ,2014) women make up $40 \%$ of the world's workforce. It is noted that many of the sectors that are critical for economic growth in some of the developing countries depend heavily on women. Small and medium-sized enterprises (SMEs) with female ownership represent $30 \%$ to $37 \%$ of all SMEs (8 million to 10 million women-owned firms) in emerging markets. These businesses have unmet financial needs of between US\$260 billion and US\$320 billion a year.

The challenge of access to finance for women-owned SME is even bigger. These SMEs are more likely to cite access to finance constraints as the first or second barrier to business than their male counterparts. Data on availability of finance to women-owned enterprises indicates that close to 70 percent of women-owned SMEs are unserved or underserved leading to a credit gap of about USD 287 billion, or about 30 percent of the total (IFC 2014).

According to an IFC report, women-owned businesses attract less than 5 percent of venture capital funding, even though their requirements for starts up are similar. Yet IFC research indicates that female borrowers have a stronger repayment history and present greater potential for cross sales compared to male entrepreneurs, making them roughly twice as profitable for banks as a consumer segment. A research by the US Small Business Administration indicates that firms that invest in women-owned businesses have higher returns on their investments (Businesswomen Network Report,2016)

The estimated population of Palestine at 2017 was about 4.70 million, divided into 2.39 million males and 2.31 million females. That means about $50 \%$ of the total populations are women (Palestinian Central Bureau of Statistics, 2017 ) . unemployment rate in the Palestine has reached a new high. It peaked at 32.4 percent in the second quarter of 2018, which is about 5 percentage points higher than its average in 2017 and the highest rate in two decades. The increase is due to a large jump in Gaza, where 53.7 percent of those in the labor force were unemployed in the second quarter of 2018. Unemployment amongst Gaza's youth exceeded 70 percent while it was even higher for females, amounting to 78 percent in the second quarter of 2018 The situation in the West Bank has been very different with the unemployment rate remaining stable at around 18-19 percent over recent 
years. (world bank,2018) The data showed an increase in poverty percentages in 2017 compared to 2011. Therefore, women's participation in the mainstream of the economy is crucial for attaining sustainable economic growth \& poverty reduction. But women participation in institutional economic sector is inadequate and the rate of women entrepreneurs is very low compared to that of male counterparts. ( Khaleque ,2018) .

\section{Literature Review}

\subsection{Women-Owned SMEs Enterprises.}

SMEs play a meaningful and significant role in contributing to economic development by creating jobs, promoting greater economic growth. There are an estimated 8-10 million formal SMEs across the world fully or partially owned by women (Baliamoune-Lutz and McGillivray, 2007). Increasing women's economic opportunities and entrepreneurship can also boost gender equality, and reduce poverty. In fact, it is predicted that a failure to achieve the third Millennium Development Goal, on gender equality, will have negative implications on per capita income growth, Furthermore, investing in women may have higher economic and non-economic returns. Women are more likely to share the rewards of these returns with others, such as their children, benefitting their health, education, and nutrition. (International Finance Corporation , 2008)

Women-owned SMEs may experience greater challenges in accessing finance. They are often more likely to cite access to finance constraints as the first or second barrier to business than their male counterparts (Kumar, 2017). They are less likely to receive a loan and receive a very small percentage of venture capital and equity funding, in contrast to men. Since women in developing countries tend to be less educated and less financially literate, they face greater constraints in accessing formal finance (Lutz and Lutz, 2017). There is also the general perception that women lack the financial capability to manage finances, in contrast to male owners or managers, who are more likely to be granted loans (Onubedo and Yusuf, 2018). These financial constraints appear to be a key factor in limiting the performance of female-owned firms in MENA (Lutz and Lutz, 2017)

In Palestinian economy, the majority of the Palestinian SMEs is initiated based on individual or family saving with little support from the official agencies. However, the major motivation for establishing new SMEs is different from one venture to another. In a study conducted to examine the background of initiations in the Palestinian economy found that $53 \%$ of ventures established by individual based on their saving and experiences to start a new venture. A quarter of the added ventures where established in the Palestinian economy by entrepreneurs without previous experience in the field. The motivation was just to invest the available savings in order to find a job as self-employed. While other ventures were established and emerged from small project to more will developed projects. (Sabri.2008)Palestinian SMEs received a substantial support of the microfinance programs run by the UNRWA The UNRWA granted about 130,000 loans for SMEs since it operated this program of a value of $\$ 120$ million up to 2007. One third of the total granted microfinance loans were directed to small firms operated by women (UNRWA, 2008). Second: The SMEs receive also financing services from specialized NGOs some of these organizations work with firms operated with women only, while others work with all small firms regardless of type of business and gender of ownership. Currently, The major NGOs institutions working as Micro finance institutions offering loans to SMEs are: Palestinian Businesswomen's Association, Palestine for Credit and Development - FATEN, Palestinian Agriculture Relief Committee - PARC, Arab Centre for Agricultural Development - ACAD, American Near East Refugees Aid - ANERA, Corporative Housing Foundation - CHF, Young Man Christian Association - YMCA, Caritas - Jerusalem (Associate member) Source;. The above NGOs include local and international firms offered about 26900 loans, with outstanding balance of about $\$ 45$ million ( Khaled et al., 2006) up to 2005. Third: there is one institute known as Palestine Development Fund which offers to SMEs microfinance services. It is considered as semi government institute and offer to both small as well as large scale firms' loans for new established firms. The fund offered about \$ 98 million to about 3000 Palestinian borrowers mainly medium scale firms (PBC, 2008).

Small, and medium enterprises (SMEs) constitute 96 percent of the Palestinian private sector (Althalathini, 2015 ), but only a $25 \%$ of these businesses are owned by women and the majority of these exist in the informal economy. (Cherie Blair Foundation for Women,2018). Few opportunities for women to participate in the labor force exist, either through corporate employment or entrepreneurship. Although 65 percent of Palestinian women have expressed a desire to launch a business, only 15 percent have done so (world bank ,2018). 
Table 1. Small and Medium Enterprises In Palestine

\begin{tabular}{|c|c|c|c|}
\hline \multirow[t]{2}{*}{ Economic Activity } & \multicolumn{3}{|c|}{ Employment Size Group } \\
\hline & $1-4$ & $5-9$ & $10-19$ \\
\hline Mining and quarrying & 115 & 147 & 45 \\
\hline Manufacturing & 14.832 & 2.721 & 1.030 \\
\hline Electricity, gas, steam and air conditioning supply & 45 & 9 & 6 \\
\hline Water Supply sewerage, waste management and remediation activities & 257 & 34 & 9 \\
\hline Construction & 474 & 183 & 108 \\
\hline Wholesale and retail trade; repair of motor vehicles & 76.384 & 3.194 & 677 \\
\hline Transportation & 700 & 302 & 181 \\
\hline Accommodation and food service activities & 7.026 & 723 & 270 \\
\hline Information and communication & 584 & 166 & 102 \\
\hline Financial and insurance activities & 834 & 219 & 183 \\
\hline Real estate activities & 349 & 33 & 15 \\
\hline Professional, scientific and technical activities & 4.208 & 506 & 122 \\
\hline Administrative and support service activities & 1.776 & 126 & 31 \\
\hline Public administration and defense; compulsory social security & 24 & 6 & 10 \\
\hline Education & 2.156 & 1.168 & 468 \\
\hline Human health and social work activities. & 5.222 & 406 & 237 \\
\hline Arts, entertainment and recreation & 2.298 & 332 & 123 \\
\hline Other service activities & 12.715 & 554 & 210 \\
\hline $\begin{array}{l}\text { Activities of householders as employers; undifferentiated goods- and } \\
\text { services- producing activities of householders for own use. }\end{array}$ & 1 & 0 & 0 \\
\hline Activities of extraterritorial organizations and bodies & 27 & 15 & 10 \\
\hline Not Stated & 0 & 0 & 0 \\
\hline Total & 130.072 & 10.847 & 3.837 \\
\hline
\end{tabular}

(Palestinian Central Bureau of Statistics ,2018)

The low representation of female entrepreneurs in West Bank and Gaza is attributed to several barriers that make it difficult for women to start and grow their businesses: ( IFC, 2017)

- Political instability: There is evidence that the political volatility resulting from violence, political division, and military rule has a limiting effect on SMEs that operate in the fragmented Palestinian domestic market (World Bank 2014).

- Lack of mobility: Geographic and social restrictions limit the ability of women —compared with men to move outside of their local communities, reducing their business growth opportunities.

- Limited business management skills: Compared with men, women entrepreneurs have less exposure to formal business training, especially in the areas of marketing and financial management, and are more likely to operate their enterprises from their homes (Althalathini 2015).

- Low confidence: Women display lower confidence in their abilities as entrepreneurs than their male counterparts (Kelly et al. 2015).

- Smaller networks: Female SMEs operate in smaller, less diverse networks than men and are less likely to seek the support of their social networks for business growth.

- Limited access to finance: Women-owned SMEs need an average of $\$ 42,000$ in financing, representing a credit gap of $\$ 147$ million across the Palestinian market .

\subsection{Previous Studies:}

(Needs Assessment of Women-owned Small and Medium-sized enterprises in Vietnam,2018) study assesses the need for support of women-owned small and medium enterprises (SMEs) in Vietnam The survey found out that $42 \%$ of women-owned SMEs have difficulty accessing financial resources . Top 5 challenges include high interest rates $(67 \%)$; inappropriate loan application and mortgage requirements $(45 \%)$; unsuitable loan term $(33 \%)$ and lack of collateral (30\%) Difficulties in accessing financial services more frequently reported by women-owned SMEs than men-owned SMEs include: no information about source of funds ( $25 \%$ for women-owned SMEs and $16.7 \%$ for men-owned SMEs), no network of referrals in accessing financial services (23\% vs. $6.3 \%)$, lack of negotiation skills ( $9 \%$ vs. $1.6 \%$ ) and lack of support from husband/family ( $5 \%$ vs. $3.2 \%$ ).

(OECD and World Bank,2018) Survey of small and medium enterprises in 42 countries responded to the survey in December 2017-January 2018, Study found (70\%) of both male- and female-owned SMEs rely on personal savings as a source of capital to fund their businesses. Analyzing funding from outside the household, significant differences emerge, with women accessing all other forms of financing at lower rates than men. Across the world, female-owned SMEs are six percentage points less likely to have relied on a loan from a bank, five 
percentage points less likely to rely on funding from friends, and three percentage points less likely to have accessed venture capital.

(SMEF Working Group Survey Report,2017 ) The purpose of study was to find out whether financial policymakers and regulators have prioritized specific SME finance policies to promote access to finance for MSMEs owned by women and women entrepreneurs. The Challenges of Increasing Access to Finance for MSMEs Owned by Women Lack of collateral, low financial literacy, the sociocultural environment, entrepreneurship skills, and lack of customized banking products were rated as the top five challenges to increasing access to finance for MSMEs owned by women, Bangladesh, Fiji, Indonesia, Ghana, Mexico and Tonga ,reported adopting specific policy programs to foster greater access to finance for MSMEs owned by women, while $46 \%$ of respondents had not.

(World Economic Forum,2017) The Surveys, designed to assess the strengths and weaknesses of enterprises from six countries: Ghana, the Gambia, Kenya, Morocco, Nigeria and Uganda. The study showed lack of suitability for SME bankability are many, both on the supply and demand side. On the supply side, these include high transaction costs, lack of collateral and high leverage ratios that arise due to unavailability of equity. Asymmetric credit information and lack of property rights and/or their enforceability also deters financial institutions to lend to SMEs.

(Woman Entrepreneurs Saskatcheewan,2018) The study aims to review literature on the issue of participation in entrepreneurship by Canadian women, The Research shows : female start up founders have to work harder and receive far less investment than their male competitors. The primary reason cited by studies is that venture capital firms have too few women on their teams, and the perspectives are often biased regarding the capability of women entrepreneurs (e.g. motherhood) to pursue a high technology business.

(Asia Pacific Foundation of Canada,2018 ) The study discussed the gender-based barriers to effective engagement in trade faced by women-owned SMEs in Indonesia. Lack of credit information is a factor that contributes to the constraints faced by SMEs as assessing their creditworthiness represents a unique challenge. Compared to larger firms, it can be more difficult for an SME to develop a credit history as they have less access to traditional sources of finance such as banks and other financial institutions whose data is typically used in the production of credit reports. registries to promote adequate legal and institutional protections, therefore, enable SMEs to access the resources they need to launch and operate their businesses.

(Symbiotics,2017) the study aims to achieve the following main objectives: $i$ to capture the financial and social value creation from financial institutions active at the base of the pyramid, in low- and middle income economies, working with SMEs; ii to foster job creation, employment and entrepreneurship, as well as more broadly the democratization of access to capital. All the SMEs in the sample are loan recipients, and therefore have access to finance through loans. Nevertheless, more than half of the SMEs reported that their own savings or wealth is the main source they use to finance their business, while $38 \%$ use loans as their main source of finance. The remaining 7\% rely on financial assistance from friends, relatives or other sources. However, only $9 \%$ of SMEs had their loan applications rejected in the past.

\section{Problem Statement}

Access to Finance is one the greatest concerns for all new ventures, but especially for women owned businesses. A recent study by the IFC estimates that about $70 \%$ of female ventures in developing and emerging countries receive no or too little funding by financial institutions in order to support and grow their ventures. The credit gap, which is the difference between the required and the actual levels of debt of a new venture, is estimated at about $\$ 280$ billion. According to the IFC, the credit gap for women in the MENA region is the largest worldwide. The lack in funding is approximately $\$ 271,000$ per women-owned SME (compared to approximately $\$ 18,700$ per women-owned SME in East Asia. ( IFC, 2014).

Despite the crucial efforts made by Palestine State and private actors such as NGOs to foster women access to financial services such as loan, women SMEs still facing specific challenges to access financial services in Microfinance Institutions in. The reasons for this could be either women SMEs lacks collaterals, poor credit history, lacks of Information and skills on how to acquire loans from microfinance institutions, lack of supportive mechanism.

Therefore this study intended to assess the challenges facing Women-Owned SMEs in Palestine in accessing loans from microfinance institutions in Palestine.

\section{General Objective:}

The study intended to assess the challenges facing Women-Owned SMEs Enterprises in accessing loans from microfinance institutions in Palestine.

\section{Research Question}

This study was guided by the following specific questions-: 
1.IS There any relationship between collateral requirements and access to finance Women-owned SMEs ?

2. IS There any relationship between business support services and access to finance Women-owned SMEs?

3. IS There any relationship between High interest on loans and access to finance. Women-owned SMEs ?

4. IS There any relationship between Procedures and the lack of Information services and access to finance Women-owned SMEs?

\section{Hypotheses}

Based on problems of the study, the researcher has developed the following study hypotheses:

- H0: There are no significant effects of collateral requirement on access to finance by Women-Owned SMEs in Palestine.

- H0: There are no significant effects of business support services on access to finance by Women-Owned SMEs in Palestine.

- H0: There are no significant effects of high interest on loans on access to finance by Women-Owned SMEs in Palestine.

- H0: There are no significant effects of lack of Information services on access to finance by Women-Owned SMEs in Palestine.

\section{Methodology:}

A structured questionnaire was administered on a random sample population of Women-Owned SMEs Enterprises in Hebron and Bethlehem, Out of the 60 questionnaires administered, 54 were filled and returned. This represented a response rate of $90 \%$. Data obtained from the questionnaires were cleverly analyzed using the Statistical Package for Social Science(SPSS). Questionnaires were administered on the owners of these SMEs and/ or representatives.

\section{Discussion of findings:}

\subsection{Reliability results}

The study used the Cronbach's alpha coefficient to determine the internal consistency of the scale that was used to measure the reliability of the variables of the study. The alpha coefficients were all greater than 0.7 , indicating an acceptable reliability of the instruments. The instrument therefore was appropriate for the study .

\subsection{Pearson's correlation matrix}

As one can observe from the correlation Table 3 the below, the correlation are used for checking multicollinearity. The correlation between each of the independent variables is not too high, meaning that the correlation is not above value 0.5 . It can be concluded that in this study there is no problem with multicollinearity. The strongest relationship between the independent variables is 0.464 between Collateral requirement, lack of Information services.

Table 2. :Pearson correlation coefficient matrix

\begin{tabular}{|c|c|c|c|c|c|}
\hline & $\begin{array}{l}\text { Collateral } \\
\text { requirement }\end{array}$ & $\begin{array}{l}\text { Business } \\
\text { support } \\
\text { services }\end{array}$ & $\begin{array}{l}\text { High } \\
\text { interest on } \\
\text { loans }\end{array}$ & $\begin{array}{l}\text { lack of } \\
\text { Information } \\
\text { services }\end{array}$ & $\begin{array}{l}\text { Access to } \\
\text { finance }\end{array}$ \\
\hline $\begin{array}{l}\text { Collateral } \\
\text { requirement }\end{array}$ & 1 & & & & \\
\hline $\begin{array}{l}\text { Business support } \\
\text { services }\end{array}$ & 0.331 & 1 & & & \\
\hline $\begin{array}{l}\text { High interest on } \\
\text { loans }\end{array}$ & 0.054 & 0.062 & 1 & & \\
\hline $\begin{array}{l}\text { lack of } \\
\text { Information } \\
\text { services }\end{array}$ & 0.464 & 0.141 & 0.065 & 1 & \\
\hline $\begin{array}{l}\text { Access to } \\
\text { finance }\end{array}$ & -0.601 & 0.540 & -0.604 & -0.584 & 1 \\
\hline
\end{tabular}




\section{Correlation Analysis for Collateral Requirements and Access to Finance:}

The result presented in Table (2) shows that there was a significant correlation between collateral requirement and access to finance by SMEs in Palestine, with p- value of 0.000 which is less than 0.05 and coefficient of correlation (R) of -0.601 while other independent variables are held constant. This implies that there was a significant relationship between collateral requirement and access to finance by SMEs. The negative coefficient of correlation value implies that there is a negative strong relationship between the collateral requirements and access to finance by SMEs in Palestine, that is, as the banks increase collateral requirements by the SMEs the access to finance by the SMEs decreases.

\section{Correlation Analysis for Business support services and Access to Finance:}

The result presented in Table (2) revealed that there was a significant correlation between Business support services and access to finance by SMEs in Palestine, with p- value of 0.000 which is less than 0.05 and coefficient of correlation $(\mathrm{R})$ of 0.540 while other independent variables are held constant. This implies that there was a significant relationship between Business support services and access to finance by SMEs in Palestine. The positive coefficient of correlation value implies that there is a positive relationship between Business support services and access to finance by SMEs in Palestine, that is, as Business support services increase access to finance by the SMEs increases.

\section{Correlation Analysis for lack of Information services and Access to Finance:}

The result presented in Table (2) revealed that there was a significant correlation between lack of Information and access to finance by SMEs in Palestine, with p- value of 0.000 which is less than 0.05 and coefficient of correlation (R) of- 0.584 while other independent variables are held constant. This implies that there was a significant relationship between lack of Information and access to finance by SMEs in Palestine The negative coefficient of correlation value implies that there is a negative relationship between Lack of Information and access to finance by SMEs in Palestine, that is, as the lack of Information services increase access to finance by the SMEs decreases. Correlation Analysis for High interest on loans and Access to Finance :

The result presented in Table (2) shows that there was a significant correlation between High interest on loans and access to finance by SMEs in Palestine, with p- value of 0.000 which is less than 0.05 and coefficient of correlation (R) of -0.604 while other independent variables are held constant. This implies that there was a significant relationship between High interest on loans and access to finance by SMEs. The negative coefficient of correlation value implies that there is a negative strong relationship between the High interest on loans and access to finance by SMEs in Palestine that is, as the interest on loan increase access to finance by the SMEs decreases.

\subsection{Regression Analysis}

Multiple regression was used to establish the relationship between the variables of the study. In doing so, the regression model below was used: $y=\beta 0+\beta 1 \times 1+\beta 2 \times 2+\beta 3 \times 3+\beta 4 x 4+\varepsilon$. where $y=$ dependent variable (access to finance); $\beta 1-\beta 4=$ model parameters or coefficients; $x_{1}-x_{4}=$ independent variables namely Collateral requirement, Business support services, High interest on loans, lack of Information services,; and $\varepsilon=$ error terms. From the results, it was found that the four independent variables moderately predict access to finance in SMEs (Adjusted R Square $=0.701$ ). These results enable to conclude that the model explains 70.1 percent of the variance in the access to finance; 29.9 percent of variations are brought about by factors not captured in the objectives.

Table 3. Model Summary for all Variables

\begin{tabular}{|c|c|c|c|}
\hline Model & R & R Square & Adjusted R Square \\
\hline 1 & 0.267 & 0.713 & 0.701 \\
\hline
\end{tabular}

A: Predictors: (constant), collateral requirement, Business support services, High interest on loans, and lack

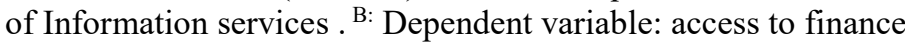

The null hypothesis was rejected because the linear regression $F$-test results $(F=4.244$; and $54 \mathrm{df})$ are significant at $p<0.05$. Therefore, the null hypothesis $\left(\mathrm{H}_{\mathrm{o}}\right)$ was rejected and concluded that the regression model linearly explains the access to finance. Therefore, the study accepted alternative hypothesis:

- H1: There are significant effects of collateral requirement on access to finance by Women-Owned SMEs in Palestine.

- H1: There are significant effects of business support services on access to finance by Women-Owned SMEs in Palestine.

- H1: There are significant effects of high interest on loans on access to finance by Women-Owned SMEs in Palestine.

- $\quad \mathrm{H}$ : There are significant effects of lack of Information services on access to finance by Women-Owned SMEs in Palestine.

Regression Analysis for Collateral Requirements and Finance and Access to Finance:

The results of simple regression analysis for Collateral Requirements and access to finance by SMEs were done and the model summary was presented in Table (4) 
Table 4 . Regression Analysis for Collateral Requirements and Access to Finance

\begin{tabular}{|c|c|c|c|}
\hline Model & R & R Square & Adjusted R Square \\
\hline 1 & -0.601 & 0.361 & 0.352 \\
\hline
\end{tabular}

a. Predictors: (Constant), Collateral Requirements, Business support services, lack of Information services, High interest on loans

b. Dependent Variable: Access to Finance by SMEs.

The results in Table (4) indicated that there was relationship between Collateral Requirements and access to finance by SMEs in which R Square was 0.361 implying that $36.1 \%$ of access to finance by SMEs was explained by Collateral Requirements. This shows that an increase Collateral Requirements by one unit causes a decrease in access to finance by SMEs by 0.361 . The adjusted R square of 0.352 means the Collateral Requirements without the constant explains $35.2 \%$ variation in access to finance by the SMEs. The remaining $64.8 \%$ variation in access to finance by the SMEs is explained by other variables which are not in this model.

Regression Analysis for Business support services and Access to Finance:

The results of simple regression analysis for Business support services and access to finance by SMEs were done and the model summary was presented in Table (2)

Table 5. Regression Analysis for Business support services and Access to Finance

\begin{tabular}{|c|c|c|c|}
\hline Model & $\mathrm{R}$ & $\mathrm{R}$ Square & Adjusted R Square \\
\hline 2 & 0.540 & 0.292 & 0.275 \\
\hline
\end{tabular}

The results in Table (5) indicated that there was relationship between Business support services and access to finance by SMEs in which R Square was 0.292 implying that $29.2 \%$ of access to finance by SMEs was explained by Business support services. This shows that an increase Business support services by one unit causes a increase in access to finance by SMEs by 0.361 . The adjusted $\mathrm{R}$ square of 0.292 means the Business support services without the constant explains $29.2 \%$ variation in access to finance by the SMEs. The remaining $70.8 \%$ variation in access to finance by the SMEs is explained by other variables which are not in this model.

Regression Analysis for lack of Information services and Access to Finance and Access to Finance:

The results of simple regression analysis for lack of Information services and Access and access to finance by SMEs were done and the model summary was presented in Table (6)

Table 6. Regression Analysis for lack of Information services and Access and Access to Finance

\begin{tabular}{|c|c|c|c|}
\hline Model & $\mathrm{R}$ & $\mathrm{R}$ Square & Adjusted R Square \\
\hline 3 & -0.584 & 0.341 & 0.330 \\
\hline
\end{tabular}

The results in Table (6) indicated that there was relationship between lack of Information services and Access and access to finance by SMEs in which R Square was 0.341 implying that $34.1 \%$ of access to finance by SMEs was explained by lack of Information services and Access. This shows that an increase lack of Information services and Access by one unit causes a decrease in access to finance by SMEs by 0.341 . The adjusted R square of 0.330 means the lack of Information services and Access without the constant explains $33.0 \%$ variation in access to finance by the SMEs. The remaining $67.0 \%$ variation in access to finance by the SMEs is explained by other variables which are not in this model.

Regression Analysis for High interest on loans and Access to Finance :

The results of simple regression analysis for High interest on loans and access to finance by SMEs were done and the model summary was presented in Table (7)

Table 7. Regression Analysis for High interest on loans and Access to Finance

\begin{tabular}{|c|c|c|c|}
\hline Model & $\mathrm{R}$ & $\mathrm{R}$ Square & Adjusted R Square \\
\hline 4 & -0.604 & 0.365 & 0.326 \\
\hline
\end{tabular}

The results in Table (7) indicated that there was relationship between High interest on loans and access to finance by SMEs in which R Square was- 0.365 implying that $36.5 \%$ of access to finance by SMEs was explained by High interest on loans. This shows that an increase High interest on loans by one unit causes a decrease in access to finance by SMEs by 0.365 . The adjusted R square of 0.362 means the High interest on loans without the constant explains $36.2 \%$ variation in access to finance by the SMEs. The remaining $63.8 \%$ variation in access to finance by the SMEs is explained by other variables which are not in this model.

\section{Conclusion and Recommendations}

9.1 Conclusions

Based on the findings of the study it can be concluded that all the independent variables (Collateral Requirements, Business support services, lack of Information services, High interest on loans) in the study affects access to finance by SMEs in Palestine. The relationship was confirmed through correlation and regression analysis which revealed that there was a negative significant linear relationship between the Collateral Requirements, lack of Information services, High interest on loans access to finance by SMEs. Regression and correlation analysis also confirmed that there is a positive significant linear relationship between Business support services, and access 
to finance by SMEs in Palestine. Regression model summary indicated that $70.1 \%$ variation in access to finance by SMEs in Palestine was explained by Independent variables.

\subsection{Recommendations}

From the findings of this research, recommendations are made to three different actors: the Government, banks and other financial institutions, and lastly SME owners.

1. Banks and other financial institutions should simplify their lending criteria and pay attention to opportunities for financing the promising SME sector rather than requiring high collateral.

2. Government should increase the little support it offers to SMEs .

3. conditions and financial system of the country do not allow SMEs to acquire finance favorably from financial institutions.

4. Banks and other financial institutions should be proactive and find innovative ways to accommodate SMEs, a typical example being to train them on how to be "bankable".

5. SMEs should maintain an internal database of all the incomings and spending made.

6. Nonfinancial services provided by the government, NGOs, and other interest groups can improve the financial performance of women-owned businesses to Reduce knowledge gaps and negative attitudes

7. The government should launch interest rate-supported programs to enable SMEs access to funds from banks and other financial institutions at low interest rates.

8. Governments and business/industry associations should improve access to information about alternative, innovative, and inclusive financial services increasing the number of intermediaries between the SMEs and the banks to reduce information asymmetry.

\section{References}

1) Althalathini, D. (2015). Women Entrepreneurs in Gaza Strip: Obstacles and Opportunities. International Journal of Economics, Commerce and Management. 4, 49-52.

2) Asia Pacific Foundation of Canada. (2018). Survey of Entrepreneurs and MSMEs in Indonesia -Canada.

3) Baliamoune-Lutz and McGillivray .(2007). Gender Inequality and Growth: Evidence from Sub-Saharan Africa and Arab Countries. African Economic Conference 2007.

4) Cherie Blair Foundation for Women. (2018).Middle East Women Entrepreneurs. "

5) Comeig, I., Fernandaze-Blanco, M.O., Ramirez, F. (2015). Information acquisition in SME's relationship lending and cost of loans. Journal of Business Research. 68, 1650-1652.

6) International Finance Corporation ( 2014),Women-Owned SMEs A Business Opportunity for Financial Institutions.

7) International Finance Corporation. (2008). Strengthening Access to Finance for Women-Owned SMEs in Developing Countries.

8) International Finance Corporation (2011). Enterprise Finance Gap Database.

9) International Finance Corporation.( 2017). Case Study: Bank of Palestine Strengthens Women-Owned Businesses and the Economy."

10) Kelly, D., Singer, S., Herrington, M.( 2015). Global report. Global Entrepreneurship Monitor.

11) Khaled, Mohammed, Kate Lauer and Xavier Reille (2006) Meeting the Demand for Microfinance in the West Bank and Gaza (CGAP, World Bank working paper .

12) Khaleque, Abdu (2018), Performance of Women Entrepreneurs: Does Access to Finance Really Matter? " Eurasian Journal of Business and Economics . 21, 23-48.

13) Kumar, R. (2017). Targeted SME financing and employment effects: What do we know and what can we do differently? Washington, DC: The World Group.http://documents.worldbank.org/curated/en/577091496733563036/Targeted-SME-financingandemployment-effects-what-do-we-know-and-what-can-we-do-differently

14) Lutz, M. B. and Lutz, S. (2017). Financing and performance of female-owned firms in Middle Eastern and African economies. Instituto Complutense de Analisis Economico, working paper. https://papers.ssrn.com/sol3/papers.cfm?abstract_id=2907977

15) OECD and World Bank. (2018). Financing and Women-Owned Small Businesses: The Role of Size ,Age and Industry ."

16) OECD,( 2016 ),MENA Businesswomen Network Report

17) Onubedo, G. and K. M. Yusuf. (2018). Finance and firm productivity in Africa: Background study from World Bank Enterprise Data Survey. Abuja. Centre for the Study of the Economies of Africa. https://www.africaportal.org/publications/finance-and-firm-productivity-africa-background-studyworldbank-enterprise-survey-data/

18) Palestinian Central Bureau of Statistics. (2008). Annul Report

19) Palestine in Figures 2007 ,PNA, Palestinian Central Bureau of Statistics, Ramallah, Palestine. 
20) Palestinian Central Bureau of Statistics. (2017) .Annul Report.

21) Sabri, N. (2008). Small Businesses and Entrepreneurs in Palestine, Working Paper Series, Birzeit University, Ramallah, Palestine.

22) SMEF Working Group Survey Report ,2017 ). Survey Report on SME Financial Polices for Micro ,Small and Medium Enterprises Owned by Women and Women Entrepreneurs". Kuala Lumpur, Malaysia .

23) Symbiotic . (2017). SME Finance Loans for Growth.UK, London .

24) World Bank. ( 2018). Innovative Private Sector Development, Palestine.

25) UNRWA (2008) UNRWA in Figures (Public Information office, United Nations Relief and Works Agency for Palestine Refugees Headquarter, Gaza, Palestine, February.

26) Vietnam Women's Entrepreneurs Council (2018)," "Needs Assessment of Women-owned Small and Medium-sized enterprises in Vietnam ."Vietnam.

27) Woman Entrepreneurs Saskatchewan,(2018). Women Entrepreneurship in Canada .Canada.

28) World Bank (2017), Targeted Financing for SME'S and Employment Effects: What Do we Know And What Could Be Done Differently? Entrepreneurship Monitor, 1-78.

29) World Bank. (2018). Economic Monitoring Report to the Ad Hoc Liaison Committee.

30) World Economic Forum ,(2017). "The Africa Competitiveness Report". Geneva.

* Dr. Adnan Qubbaja

The author was born in Palestine in 1965. He got Master degree in finance from Jordan University at 1994, Phd in Finance from Jordan in 2008. Senior Researcher at Palestine Economic Policy Research Institute (MAS). Also, Doctor of finance in Hebron ,Alquds open university, Head of Financial and Banking Science Department Palestine Ahliya University-Bethlehem "till now" 